\title{
Sole Haemorrhages in Tied Heifers in Early Gestation as an Indicator of Laminitis: Effects of Diet and Flooring
}

\author{
By C. Bergsten and B. Frank
}

Experımental Station, Swedish Unıversity of Agricultural Sciences, Skara and Department of Agricultural Biosystems and Technology, Swedish University of Agnicultural Sciences, Alnarp, Sweden.

\begin{abstract}
Bergsten, C. and B. Frank: Sole haemorrhages in tied heifers in early gestation as an indicator of laminitis: Effects of diet and flooring. Acta vet. scand. 1996, 37, 375382. - The influence of feeding a high concentrate diet and of different types of floor surface on the prevalence and severity of haemorrhages of the sole horn was studied in 60 Swedish Friesian heifers during early pregnancy. For 4 weeks, out of a total observation period of 17 weeks, half the anımals were offered $6.5 \mathrm{~kg} /$ day of concentrates while the others were fed a standard diet consıstıng mainly of roughage. Half the anımals were kept on rubber mats and half on a concrete floor. The hooves were trimmed and the soles were photographed at the start and at the end of the experiment. The photographs were evaluated, each claw was scored for sole haemorrhages, and the total score for all 8 claws was calculated. No differences were observed between the groups in the scores of sole haemorrhages at any trimming. The scores were significantly higher at the first than at the second trimming, probably as a consequence of an abrubt change of floor surface 2-3 months before the first trimming. The study provides indirect evidence that events relating specifically to calving are likely to be crucial risk factors for sole haemorrhages and laminitis.
\end{abstract}

concentrate diet; concrete floor; foot disease; rubber mat.

\section{Introduction}

Laminitis (Pododermatitis aseptica diffusa) in cattle is a multifactorial disease of which the aetiology and pathogenesis are not fully understood. Its clinical signs are variable in their progress and severity (Nilsson 1963, Andersson \& Liberg 1980) and a subclinical form is common in housed dairy cattle (Peterse 1980, Enevoldsen et al. 1991, Bergsten 1994). Both the clinical and subclinical forms of the disease can be revealed retrospectively by the appearance of sole haemorrhages, which occur most commonly 2 to 4 months after calving (Peterse 1980 , Bergsten et al. 1986). Sole haemorrhages are considered to be an early stage of sole ulcer (Pododermatitis circumscripta) and white line disease (Pododermatitis zona alba), complications which are quite common in dairy cattle (Edwards 1982, Greenough 1985). Clinical laminitis and sole haemorrhages have also been observed in young heifer calves and pregnant heifers (Bradley et al. 1989, Greenough \& Vermunt 1991, Bargai et al. 1992, Frankena et al. 1992), and in male cattle of various ages (MacLean 1966, Greenough \& Gacek 1987, Rousseau \& Fostier 1988, Greenough et al. 1990). However, the lesions in these types of cattle are less severe and usually regress spontaneously without complications. Many risk factors for laminitis in dairy cattle have been discussed; among the most important factors 
are high levels of concentrate feeding and concrete flooring.

The aim of this investigation was to study the effects of diet and flooring as risk factors for laminitis; the incidence of sole haemorrhages was estimated in groups of tied heifers in early gestation which were fed either a high or low concentrate diet and housed in accommodation with different types of flooring.

\section{Materials and methods}

\section{Animals}

The experiment used 60 Swedish Friesian heifers which were the offspring of 8 sires. They were born in the herd of the University Research Station, Alnarp, between July 1984 and January 1985 . They all grazed from May to October 1986, and during that time they received no supplementary feed except for a vitaminized mineral supplement. At the beginning of the experiment they ranged in age from 24 to 30 months.

\section{Accommodation}

The trial lasted from the end of January to the end of May 1987, while the animals were housed. The barn was provided with a section with tie-stalls and a section with cubicles.

The tie-stall section had short stalls $(1.8 \mathrm{~m} \times 1.3$ $\mathrm{m}$ ) with a concrete floor and a partition between each animal. The heifers were tied with crossties and had individual mangers (Fig. 1). Half the stalls had rubber mats. Sawdust and chopped straw were provided twice a day as bedding.

The cubicles $(2.2 \mathrm{~m} \times 1.2 \mathrm{~m})$ had a concrete floor and an edge ( $10 \mathrm{~cm}$ height $)$ at the rear to keep a layer of sawdust which was provided as bedding. The alleyways had concrete slats, and the feeding gates were self-locking.

\section{Experimental procedure}

All the heifers were housed in the cubicle sec- tion in November 1986 and fed straw ad libitum and a vitaminized mineral supplement. They were synchronized and then artificially inseminated between November 1986 and January 1987; their expected calving dates were from August to November.

In the middle of January they were all moved to the tie-stall section and assigned to 4 groups, balanced as far as possible with respect to age, sire and live weight. Two of the groups were randomly accommodated in stalls with concrete floors (C) and 2 in stalls with rubber mats (R). The 2 groups on each type of floor were then assigned to be fed either a standard diet (S) or a high concentrate diet $(\mathrm{H})$, as illustrated in Table 1.

For 2 weeks all the animals were fed the standard conventional diet, and then during the next 2 weeks an attempt was made to adapt the high concentrate group gradually to a diet containing $9 \mathrm{~kg}$ /day of concentrates. However, some of them developed diarrhoea and the final amount of concentrates was reduced to $6.5 \mathrm{~kg} /$ day. This full concentrate diet was then fed to the high concentrate group for 4 weeks, after which the

Table 1 The mean dally consumption of the different feedstuffs, dry matter (DM), metabolizable energy (ME) and digestible crude protein (DCP) by the heifers fed the standard and high concentrate diets. The standard diet was fed to 2 of the groups of helfers throughout the experiment and the high concentrate diet was fed to the other 2 groups for 4 weeks.

\begin{tabular}{lcc}
\hline Diet & Standard & $\begin{array}{c}\text { High } \\
\text { concentrate }\end{array}$ \\
\hline Beet pulp sllage, kg DM & 3.0 & 1.0 \\
Straw, kg & 4.0 & 3.8 \\
Grain*, kg & 0.4 & 6.5 \\
Rape seed meal, kg & 1.0 & - \\
DM, kg & $7-7$ & 10.0 \\
ME, MJ & 71 & 105 \\
DCP, g & 542 & 496 \\
\hline
\end{tabular}

* Barley $50 \%$, Oats $50 \%$. 

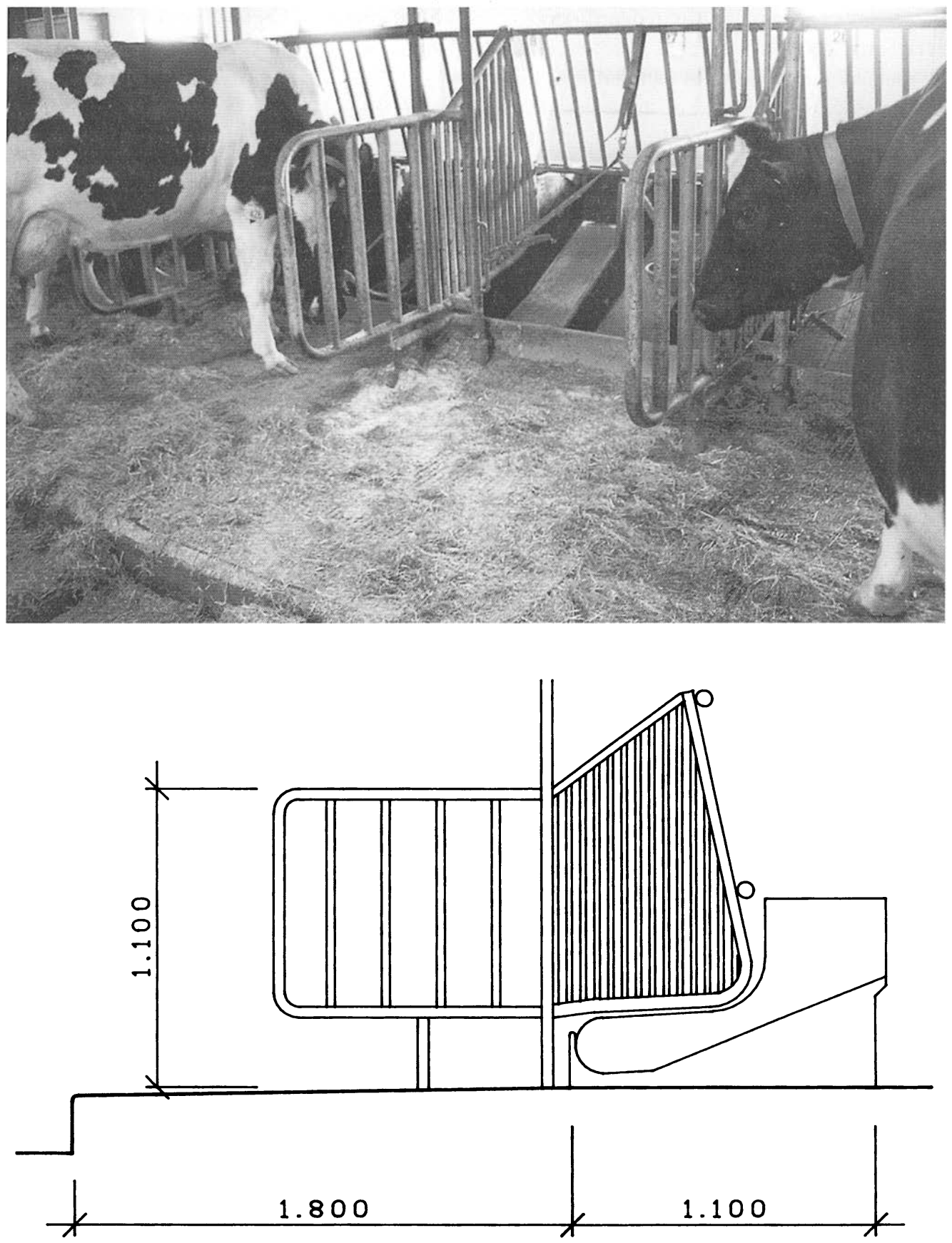

Figure 1. The design of the tie-stalls. 
amount of concentrates was reduced successively over 2 weeks until they were receiving the standard diet, which was then fed for a further 7 weeks until the end of the experiment. The group fed the standard diet received this diet throughout the experiment.

The animals were weighed at the beginning and end of the experiment. The mean weights (sd) at the beginning were $504(46) \mathrm{kg}, 506(47) \mathrm{kg}$, 509 (46) $\mathrm{kg}$ and 509 (54) kg, for groups SR, SC, $\mathrm{HR}$ and $\mathrm{HC}$, respectively.

\section{Records of haemorrhages of the sole horn}

The hooves of all the animals were trimmed in the second pre-experimental week and again at the end of the experiment 16 weeks later. The surface of the sole was photographed on both occasions by the technique of Bergsten (1993). The sets of photographs were evaluated together by 2 people who had no knowledge of the groups to which the animals belonged, and they were assigned scores on a 6-point scale:

$0=$ no haemorrhages

$1=$ slight haemorrhages covering a small area

$2=$ slight haemorrhages covering a large area

or moderate haemorrhages covering a small area

$3=$ moderate haemorrhages covering a large area

$4=$ severe haemorrhages covering a small area

$5=$ severe haemorrhages covering a large area or exposed corium (sole ulcer).

\section{Statistical analysis}

The scores for all the claws of each animal were added together, and median scores were calculated for each group. The difference between the scores observed at the first and second trimming was calculated and termed the net score. The differences between the scores of the groups were analysed by the Kruskal-Wallis non-parametric test (Kruskal \& Wallis 1952) and associations between the scores and the weights by linear regression (SAS Institute Inc 1987).

\section{Results}

The median and $10 \%$ and $90 \%$ quantiles of the haemorrhage scores of the 4 groups of heifers are shown in Table 2. All the groups of heifers had higher scores at the first trimming than at the second $(p<0.001)$, but there were no significant differences between the scores of the 4 groups at either trimming or between their net scores. No clinical lameness was observed, although a few animals in each group adopted an awkward stance for a short period. None of the animals had a score of 3 or more on a single claw at any trimming.

The animals fed the high concentrate diet gained in weight by an average of $746 \mathrm{~g} /$ day during the experiment, significantly more than the animals fed the conventional diet which gained on average $652 \mathrm{~g} /$ day $(\mathrm{p}<0.05)$. A significant $(p<0.05)$ positive association between the score at second trimming and the weight difference from the beginning to the end of the experiment was found among animals on concrete stalls. However, no association was found between the score at first trimming and any recorded weight.

\section{Discussion}

The different diets and different floors had no significant effect on the scores of sole haemorrhages in the 4 groups of heifers. However, the scores were higher at the end of January than at the end of May and this result was probably due to the abrupt change of floor surface when, in November, the heifers were brought off grass into the cubicle section of the barn which had a floor with concrete slats. Bradley et al. (1989) observed that 18-month-old Holstein heifers developed moderate to severe haemorrhages of 
Table 2. The median and $10 \%$ and $90 \%$ quantile haemorrhage scores in the sole horn of all the claws of each group of heifers ( $\mathrm{N}=$ number of animals) before and after the experimental period, and the difference between them (net score). The groups were fed either a standard diet $(\mathrm{S})$ or a high concentrate diet $(\mathrm{H})$, and were housed on either a concrete floor $(C)$ or rubber mats $(R)$. NS $=$ not significant $(p>0.05$, Kruskal Wallis test).

\begin{tabular}{|c|c|c|c|c|c|c|c|c|c|c|}
\hline \multirow[b]{3}{*}{ H C } & \multirow{3}{*}{$\begin{array}{c}\mathrm{N} \\
15\end{array}$} & \multicolumn{3}{|c|}{ Before } & \multicolumn{3}{|c|}{ After } & \multicolumn{3}{|c|}{ Net score } \\
\hline & & \multirow{2}{*}{$\begin{array}{c}\text { Median } \\
4.0\end{array}$} & \multicolumn{2}{|c|}{$10 \%, 90 \%$} & \multirow{2}{*}{$\begin{array}{c}\text { Median } \\
1.0\end{array}$} & \multicolumn{2}{|c|}{$10 \%, 90 \%$} & \multirow{2}{*}{$\begin{array}{c}\text { Medıan } \\
-3.0\end{array}$} & \multicolumn{2}{|c|}{$10 \%, 90 \%$} \\
\hline & & & 0 & 6 & & 0 & 2 & & -5 & 1 \\
\hline S C & 15 & 2.0 & 1 & 7 & 2.0 & 0 & 3 & -1.0 & -4 & 0 \\
\hline H R & 15 & 4.0 & 2 & 8 & 1.0 & 0 & 3 & -2.0 & -8 & 0 \\
\hline S R & 15 & 4.0 & 1 & 8 & 1.0 & 0 & 2 & -2.0 & -6 & 0 \\
\hline Sign. & & \multicolumn{3}{|c|}{ NS } & \multicolumn{3}{|c|}{ NS } & \multicolumn{3}{|c|}{ NS } \\
\hline
\end{tabular}

the sole horn when they were housed on concrete slats, but that the lesions had disappeared when they were examined 3 months later. Greenough \& Vermunt (1991) also related sole haemorrhages in heifers in early pregnancy to their abrupt introduction to concrete, slatted flooring, and Frankena et al. (1992) found that female dairy calves housed on concrete slats had considerably more sole haemorrhages than animals kept on straw.

There was no difference between the scores of the heifers kept on rubber mats or concrete, even in May, when they had been used to the different surfaces for 4 months. In contrast, Bergsten (1994) found that rubber mats reduced the risk of haemorrhages of the sole in lactating dairy cows, even when they had been used to a life indoors. The heifers in the present experiment were relatively heavy, and it is therefore probable that the different results were attributable to the fact that the cows were lactating and receiving a lactation diet, rather than to the fact that the load on their hooves was particularly heavy. In spite of the fact that the scores were lower at the second trimming a positive association with weight gain was present in the 2 groups on concrete floor. It seems possible that any such effect was suppressed in the groups on rubber mats. Greenough \& Vermunt (1991) found an association between weight at breeding and sole haemorrhage score from 4 months before calving, whereas no such relations were found in the present study.

The vague effect of the rubber mats on these young animals, which were accustomed to a life indoors, seems reasonable, but the lack of effect of the high concentrate diet was surprising. For example, it has been reported that high concentrate diets increased the prevalence of sole haemorrhages in feed-lot calves and yearlings (Greenough et al. 1990), bullocks (Rousseau \& Fostier 1988) and dairy calves (Bargai et al. 1992), and MacLean (1966) related laminitis to the feeding of high levels of barley in young intensive beef units. On the other hand, clinical signs of laminitis are uncommon among beef animals raised in systems which provide free access to concentrates and very restricted amounts of roughages in Sweden. It is possible that if the animals could have been fed the full planned amount of $9 \mathrm{~kg} /$ day of concentrates or fed the diet during a longer period, significant differences might have been observed.

Haemorrhages in the distal surface of the sole horn are the result of a pathological disturbance in the corium about 2 to 4 months earlier ( $\mathrm{Pe}$ terse 1980, Bergsten et al. 1986). The interval varies according to the load on the hooves and the rates of growth and wear of the horn. In this experiment the hooves were trimmed for the 
second time 13 weeks after the heifers had begun the high concentrate diet and 7 weeks after they had returned to the standard diet. The hooves were trimmed stepwise to reveal all the haemorrhages, and there was therefore little risk of missing any of them.

The lack of any significant increases in the incidence of haemorrhages in the hooves of these heifers during early pregnancy, either as a result of eating a high concentrate diet or housing on concrete floors, provides indirect evidence that events related to the periparturial period are likely to be crucial for the development of aseptic inflammation of the hoof corium. This inflammation is responsible for the laminitis and haemorrhages in the sole observed from 2 months later. It seems likely that a change in the hormonal pattern, or some other undefined factor operating during the peripartal period, increases the susceptibility of cows to other risk factors such as diet and the type of flooring.

\section{Acknowledgement}

The investigation was supported by the Swedish Counc1l for Forestry and Agricultural Research and by the Swedish Farmers' Foundation for Research.

\section{References}

Andersson L, Liberg $P$. Blood serum and synovial fluid in bovine laminitis and arthritıs, with particular reference to the proten composition. Acta vet. scand. 1980, 21, 567-577.

Bargai U, Shamir I, Lublin A, Bogin E $\cdot$ Winter outbreaks of lamınitis in dairy calves: Aetıology and laboratory, radiological and pathological findings. Vet. Rec. 1992, 131, 411-414.

Bergsten $C$ - A photometric method for recording hoof diseases in cattle, with special reference to haemorrhages of the sole. Acta vet. scand. 1993, 34, 281-286.

Bergsten C: Haemorrhages of the sole horn of dairy cows as a retrospective indicator of lamınitis: An epıdemiological study. Acta vet. scand. 1994, 35, 55-66.

Bergsten C, Andersson L, Wiktorsson H: Effect of feeding intensity at calving on the prevalence of subclinical laminitıs. Proc V Int. Symp. Disord. Ruminant Digit, Dublin, Ireland, 1986, pp. 34-38.

Bradley HK, Shannon D, Nellson DR. Subclinical laminitıs in darry he1fers. Vet Rec. 1989, 125, 177-179.

Edwards $G B$ Acute and subacute laminitis in cattle Vet. Ann. 1982, 22, 99-106.

Enevoldsen C, Gröhn YT, Thysen I. Sole ulcers in dairy cattle Association with season, cow characterıstıcs, disease, and production. J. Dairy Sci. 1991, 74, 1284-1298.

Frankena $K$, van Keulen KAS, Noordhuızen JP, Noordhuizen-Stassen EN, Gundelach J, de Jong $D$-J, Saedt I $\cdot$ A cross-sectional study into prevalence and risk indicators of digital haemorrhages in female dairy calves. Prev Vet. Med. 1992, 14, $1-12$.

Greenough PR: The subclinical laminitis syndrome. Bovine Pract 1985, 20, 144-149.

Greenough PR, Gacek Z A prelıminary report on a laminitis-like condition occurring in bulls under feeding trials Bovine Pract 1987, 22, 176-178.

Greenough PR, Vermunt JJ Evaluation of subclinical laminitis in a dairy herd and observations on associated nutritional and management factors. Vet. Rec. 1991, 128, 11-17.

Greenough PR, Vermunt JJ, McKinnon JJ, Fathy FA, Berg PA, Cohen DH: Laminitıs-like changes in the claws of feedlot cattle. Can. Vet. J. 1990, 31, 202-208.

Kruskal WH, Wallis WA: Use of rankıngs on one criterion variance analysis. J. Amer. Stat. Ass. 1952, 47, 583-621 (corrections appear in 48, pp. 253265).

MacLean CW. Observations on laminits in intensive beef units. Vet. Rec. 1966, 78, 223-231.

Nilsson $S A \cdot$ Clinical, morphological and experimental studies of laminitis in cattle. Acta vet. scand. 1963, 4, Suppl. 1.

Peterse $D J \cdot$ De beoordeling van de runderklauw op basis van het optreden van zoollaesies (Judgement of bovine claws by the occurrence of sole lesions). PhD Thesis, Rijksuniversiteit, Utrecht, the Netherlands, 1980. (In Dutch).

Rousseau JF, Fostier $B$. Boitenes des taurillons: éléments acquis à l'issue d'une enquête (Lameness in young bullocks: results of an investigation). Le Point Vétérinaire 1988, 20, 25-33. (In French).

SAS Institute Inc S SAS/STATTM: Guide for personal computers. Version 6. Edition, Cary, NC, USA, 1987. 


\section{Sammanfattning}

Sulblödningar som indikation på fång hos uppbundna kvigor $ı$ tıdıg dräktighet ınverkan av utfodring och båspallsunderlag

Inverkan av utfodrıng med en hög kraftfodergiva och olıka båspallsunderlag på förkomsten och graden av sulblödnıngar studerades hos 60 SLB-kvigor 1 tıdig dräktıghet. Under en 17 veckors observatıonsperıod gavs hälften av djuren under fyra veckor en daglig kraftfodergiva bestående av $6,5 \mathrm{~kg}$ spannmål samt grovfoder medan övriga djur erbjöds en normalfoderstat huvudsaklıgen bestående av grovfoder Hälften av djuren var uppstallade på gummımatta och hälften på betong-båspall. Klövarna på samtliga djur verkades och klövsulorna fotograferades i början och slutet av forsöket Klövbilderna bedömdes och sulblödningar på varje klövhalva poängsattes varefter poàngen från de 8 klövhalvorna summerades och angavs som sulblodnıngspoäng Inga skıllnader kunde iakttagas mellan de olıka grupperna vid någon av verknıngarna. Sulblödnıngspoängen var högre vid första verknıngen an vid den andra, troligtvis som en följd av en plötslig installnıng till betongspalt 2-3 månader före den första verknıngen. Resultaten utgör indırekt en indıkation på att kalvnıngen 1 sig är en huvudsaklıg rıskfaktor för sulblödnıngar och fång.

(Recelved June 21, 1995, accepted June 14, 1996)

Reprints may be requested from C. Bergsten, Experımental Statıon, Swedısh Unıversity of Agricultural Sc1ences, P.O.Box 234, S-532 23 Skara, Sweden. Fax +46 (0)511 67134, e-ma1l· christer.bergsten@fg.slu se 
